\title{
装いの枠組みによる瘦身の心理的機能と効用についての確認 ${ }^{1)}$ ——体型結果予期の分類および瘦身願望との関連
}

\author{
鈴 木 公 啓
}

東京未来大学

瘦身は「装い」の1つであり，装いと同様の機能を有していると考えられる。そこで，装いとしての瘦身 の性質を確認するために，心理的機能を中心に体型結果予期を用いて確認することにした。研究 1 では，若 年女性を対象として得られた自由記述データをもとに体型結果予期の分類をおこなった。その結果，装い の心理的機能に対応した内容が抽出され，瘦身が装いの1つであることが確認された。また，他の装いを促 進するという機能も確認された。研究 2 では, 体型結果予期と瘦身願望との関連について検討した。その結 果, 心理的機能に対応する体型結果予期は, 他の機能に対応する体型結果予期と同様に, 瘦身願望と正の 関連にあることが示された。

キーワード：瘦身希求行動（ダイエット），装い，心理的機能，結果予期，瘦身願望

\section{問題および目的}

「装い」は，外観を変化させることを意味する。 同様の内容を意味する用語には，「化粧」や「身 体装飾」などがある。装い（化粧，身体装飾）に は，化粧品による化粧（狭義の化粧），衣服によ る着装, アクセサリーなどによる装飾, 整髪・染 髪, そして, ダイエッティングやボディビルディ ング，ピアッシング，入墨，美容整形，そして首 輪により長い首にすることなど，外観変化のため のあらゆることが含まれる (cf., Demello, 2007; 石田, 2000 ; 石井, 2003)。これまで, 種々の装

1）本論文は, 東洋大学大学院社会学研究科に提出した 博士論文の一部に加筆・修正したものである。御指 導頂いた東洋大学教授安藤清志先生に感謝申し上げ る。なお, 本論文の一部は, 日本グループ・ダイナ ミックス学会第 54 回大会, および, 東洋大学 21 世 紀ヒューマン・インタラクション・リサーチ・セン ター研究年報第3号にて発表した。
いの位置づけや性質について考察されており (e.g., Demello, 2007; 石田, 2000 ; 石井, 2003; Roach-Higgins \& Eicher, 1992), その実証的検討 も試みられてきた（鈴木，2005）。なお，「装い」 という言葉は, 外観変化後の状態のことも意味す る。そのため, 化粧をおこなった状態, アクセサ リーやピアスを身につけた状態, 体型を変化させ た状態, 入墨を入れた状態なども「装い」が意味 するところとなる。

上述のように，外観の構成要素の1つである体 型を変化させることも, 装いの 1 つとみなされ る。例えば, 瘦せた体型を目指しておこなわれる ダイエッティングも, 引き締めた健康的な体型を 目指すエクササイジングも, そして, 鍛え上げた 体型を目指すボディビルディングも, 装いの $1 つ$ である。装いが状態や様子も示すという点では, 外観の一状態である瘦身体型（以下，瘦身）も, 引き締まった体型も, 筋肉が隆起した体型も, 装 いの1つということになる。これまで, 狭義の化 
粧, 着装, そして入墨などについては, その機能 や効用，または心理プロセスなどについて，装い の枠組みの中での検討がなされてきた。しかし, ダイエッティングやエクササイジングなどについ ては，そのような検討はほとんどおこなわれてい ない。

瘦身を求めダイエッティング (以下, 瘦身希求 行動）を抢こなう者が多い現状（平野，2002； 倉元, 2000）において, 瘦身希求行動や瘦身を 装いの枠組みで検討することは, これまでにない 有用な知見をもたらす可能性がある。それは, 瘦 身希求行動という装いの現象理解のみならず, 過 度の瘦身希求行動への介入にも寄与し得ると考え られる。従来, 瘦身希求行動や瘦身願望について は, 各領域にて多様な観点からの検討がなされて きた。主なものとしては, 臨床心理学や精神医学 の領域における, 瘦身願望を摂食障害の発症要因 (e.g., Rojo, Livianos, Conesa, Garcia, Dominguez, Rodrigo, Sanjuan, \& Vila, 2003), または, 食行 動異常の発症要因 (e.g., McFarlane, Polivy, \& McCabe, 1999）とした検討などが挙げられる。 しかし, これまでの観点による検討は, 扱ってい る内容や範囲が限定されており, そのため, 得ら れた知見とその応用に限界がある。例えば, 上述 のような摂食障害の枠組みで得られた瘦身希求行 動の心理に関する知見を, 摂食障害に必ずしも至 るわけではない一般女性に適用できるとは限らな い。多くの一般女性が瘦身を目指して瘦身希求行 動をおこなっている現状に鑑みるに，装いといっ たより一般的な観点からの検討が，その背景にあ る心理を明確にするのに有用な可能性がある。例 えば, 装いにみられる自己や他者に対する肯定 的な働きなどが瘦身にも見出される可能性があ る。

瘦身希求行動や瘦身が装いの1つであるとする と, 装いの重要な機能の 1 つである心理的機能と 同様の機能が瘦身にも存在すると考えられる。さ らに, 心理的機能に対応した心理的効用も同様に
存在すると想定される。人々はその効用を認知し て瘦身を求めている可能性がある。

これまで，装いはさまざまな心理的効用を生じ させることが知られており，その分類が試みられ てきた。例えば, 飽戸（1982）は, 化粧意識の検 討をおこない, 主要な2つの効用として,「自己 満足因子」と「個性化・競争因子」を見出してい る。また, 松井・山本・岩男 (1983) は, 化粧の 心理的効用について, 複数の効用を仮定したうえ で検討し,「化粧中の満足」,「対人的効用」,「心 の健康」の3つに大別している。これまでの心理 的効用についての検討から, 心理的効用には, 自 身に対するものと他者に対するものがあることが 確認されている。

そして, 心理的効用の内容をもとに, 装いには 「対自的機能」と「対他的機能」の2つの心理的 機能の存在が仮定されてきた（e.g., 飽戸，1982； 大坊, 1997 ; 藤原, 1987 ; 神山, 2003 ; 尾田・ 橋本・柏尾·土肥, 2003 ${ }^{2)}$ 。対自的機能とは, 自分の目をとおして生じる働きであり，自信が向 上する，積極的行動をおこなえるようになるなど の効用を生じさせるものである。対他的機能と は, 他者の目をとおして生じる働きであり, 同性 や異性から魅力的と評価されるなどの効用を生じ させるものである。これらの心理的機能は装いで ある瘦身にも認められると考えられる。

そこで本研究では, 瘦身の心理的効用について の検討をとおし, 装いとしての瘦身の心理的機能 について明確にすることを目的とする。瘦身の心 理的効用に対する人々の認知を明確にすること は, 瘦身の心理的機能を明確にし, また, 瘦身を 求める背景にある心理の解明に寄与するであろ う。さらに, 瘦身の心理的機能が装いのそれと同 様であるとしたら, 瘦身が装いの1つであること の確認にもなるであろう。

2）研究者によって用語は異なっているが, 基本的に類 似した内容とみなすことが可能である。 
今回は, 効用に対する認知として,「体型結果 予期」を扱う。これは, 瘦身をポジティブな目標 と設定した場合の，体型によって生じる結果につ いての予期であり ${ }^{3)}$ ，体型の効用についての予期 と言い換えることもできる。この体型結果予期に は，瘦身によりポジティブな評価が得られるとす る予期（以下，体型ポジティブ結果予期）と, 現 在の体型（非瘦身）によりネガティブな評価が得 られるとする予期（以下，体型ネガティブ結果予 期）の2つが想定される ${ }^{4)}$ 。前者は, 瘦せた体型 であることにより他者から賞賛してもらえる, 瘦 せることにより自信が持てるようになるといった 内容である。後者は，現在の（瘦せていない）体 型では他者から良い評価を得られない, 服の選択 肢が限定されるといった内容である。

体型結果予期に類似した内容については, これ までの研究において，いくつかの観点による分類 がなされ，扱われてきた。例えば，瘦せのメリッ トや現在の体型のデメリットといった観点からの 検討である5)。杉森（1999）は, 瘦せメリットに ついて扱い，ダイエット方法や摂食障害に関する 尺度との関連について検討している。また, 羽鳥 （1999）は瘦身に対する4つのメリット意識（自 己価值の確認, ファッション, 対人関係, 身体変 化）を扱い，そのメリット間のモデルを提示して いる。馬場・菅原 (2000) は, 瘦せた場合のメリッ 卜感, 現体型のデメリット感を含むモデルを検討

3）肥満をポジティブな目標と設定した場合の, 体型に よって生じる結果についての予期も存在するが，こ こでは, 本研究の背景にあわせて, 本文記載内容に 限定する。

4）目標表象にはポジティブとネガティブがあり, 制御 理論など, 多くの理論にてその軸が顕在的・潜在的 に扱われてきた。本研究でも, 瘦身という目標表象 の達成についての予期を扱っていることから, ポジ ティブとネガティブを想定し扱うこととした。

5）先行研究ではそれぞれ独自の用語で表現されてい る。各先行研究の紹介においては, そこで使用され た用語を用いる。
し, 瘦身願望はメリット感が直接規定し, また, デメリット感と瘦身願望はメリット感が媒介して いることを示している。浦上・小島・沢宮・坂野 （2009）も同様の内容を扱い, メリット感が直接 的に, デメリット感が直接・間接的に瘦身願望に 関連していることを示している。ほかには, 自己 評価の信念といった観点からの検討（松本・熊 野・坂野・野添, 2001), 理由や動機といった観 点からの検討（廣金·木村 · 南里 · 米山・齊藤, 2001; McArthur \& Howard, 2001; 西岡 · 矢崎 · 岩 城・桜井・原田・大澤, 1993), そして, それ以 外にもさまざまな観点からの検討 (e.g., Paxton, Wertheim, Gibbons, Szmukler, Hillier, \& Petrovich, 1991; Sabiston \& Crocker, 2005; Santoncini, Garcia, \& Peresmitre, 2006; Spangler \&Stice, 2001)が抢こなわれてきた。なお, 体型 ではなく瘦身希求行動そのものの利益や損失など についての分類もおこなわれてきた（赤松・大 竹 -島井, 2003; Allen, Thombs, Mahoney, \& Daniel, 1993; O'Connell \& Velicer, 1988; Silberstein, Striegel-Moore, Timko, \& Rodin, 1988)。

このように，これまでさまざまな観点からの分 類がおこなわれてきたが, 装いの枠組みで体型結 果予期を検討するにあたり，従来の研究で扱われ ている内容をそのまま用いることはできないと考 えられる。それは, 主に以下の3つの理由による。 1つ目は, 内容の弁別の問題である。例えば, 馬 場・菅原（2000）では瘦身のメリットや現在の体 型のデメリットが扱われているが, 性格や人生な どの複数の内容が 1 つにまとられており，個別 の内容についての検討は十分になされていない。 2つ目は, 扱われている内容の種類についての問 題である。これまで扱われた項目は, 調査者自身 が設定したものや（羽鳥，1999），摂食障害患者 の面接から得られたものであり (Spangler \& Stice, 2001), 実際に一般の人々が意識している 内容を必要十分に網羅していない可能性がある。 
3つ目は, ネガティブ（損失，デメリット，等） の内容の意味が異なるという問題である。例え ば, O’Connell \& Velicer (1988）や Allen et al. （1993）で扱っている内容は，あくまでも瘦身希 求行動を抢こなうことのポジティブな予期やネガ ティブな予期であり，体型についてのそれではな (6)。今回, 瘦身を装いの枠組みで検討する際に は, 内容を幅広く, そして適切に扱う必要がある。 そのため, 改めて内容の収集と精査が必要とな る。

本論文の第一の目的は，体型結果予期の内容の 分類と検討をおこない，装いの心理的機能と同様 の心理的機能が瘦身にも存在していることを確認 することである。瘦身が装いの1つであるならば, 瘦身にも対自的機能や対他的機能が存在し, それ らに対応する効用が生じていると考えられる。と ころで，装いには心理面以外の機能や効能も存在 する。例えば，装いはもともと身体保護を目的と しておこなわれ始めたという側面もある（e.g., Kligman, 1985 早川訳・監修 1988)。アイメーク は日差しから目を保護し，また，虫による伝染病 を防ぐという効用があったといわれている。涅歯 (いわゆるお歯黒) は, 虫歯を防ぐという効用が あったとされている。このような装いの身体保護 機能は，現代の装いにおいてもみとめられる (Kaiser, 1985)。装いの1つである瘦身にも，こ の働きが見られる可能性がある。また，その他の 機能，そしてそれに対応する効用の存在も知られ ている。例えば化粧によるリラックスなどの感情 面（e.g., 松井他, 1983)，そして生理面（e.g., 松 井他, 1983 ; 余語・浜・津田・鈴木 ·互, 1990) での効用である。このような心理面以外の内容が 得られる可能性も想定される。さらに, 瘦身独自 の内容が得られる可能性もある。その点について も併せて検討する。

6）例えば，損失の場合は，ダイエットをすると好きな ものを食べられない，といった内容である。
本論文の第二の目的は, 体型結果予期と瘦身願 望との関連について明らかにすることである。特 に, 対自的機能と対他的機能に対応する体型結果 予期と瘦身願望の関連に焦点をあて，他の予期と 瘦身願望の関連と比較しつつ検討する。体型ポジ ティブ結果予期と体型ネガティブ結果予期は, 両 者ともに瘦身をポジティブな目標として設定した 場合の予期となっている。そして，先述のとおり 問題が見られるとはいえ，体型についてのメリッ 卜意識やデメリット意識などの今回と類似した内 容を扱ったこれまでの研究により，それらと瘦身 願望との関連が示されている（e.g., 馬場・菅原, 2000 ; 羽鳥, 1999 ; 浦上他, 2009)。これらを併 せて考えると，体型結果予期と瘦身願望との間に は，正の関連が想定される。

なお，今回は瘦身志向が顕著である若年女性を 対象に検討をおこなう。

\section{研 究 1}

\section{目 的}

自由記述データの分類から，装いにおける心理 的機能に対応する内容の体型ポジティブ結果予期 と体型ネガティブ結果予期が抽出されることを確 認する。

\section{方 法}

対象 関東圈の共学の大学 1 校と女子大学 1 校 の女子学生 69 名, および, 看護学校 1 校の女子学 生 33 名の計 102 名 (平均年齢 20.58 歳, 標準偏差 1.52）を対象とした。

時期 2004 年 11 月から 2005 年 1 月に実施し た。

調査票 体型ポジティブ結果予期の内容を検討 するために, 瘦せた場合, そして瘦せている場合 のメリットについて自由記述で回答を求めた。ま た，体型ネガティブ結果予期の内容を検討するた めに，太った場合，そして太っている場合のデメ リットについても自由記述で回答を求めた。な お，実際に経験したものおよび想像のものの両方 
について記述を求めた7)。

実施方法 主に講義中に実施した ${ }^{8)}$ 。倫理的な 配慮をおこない，同意を得た者のみを調査対象と した。

\section{結果および考察}

体型ポジティブ結果予期と体型ネガティブ結果 予期のそれぞれについて，得られた記述内容の分 類をおこなった。前者については205の記述が得 られた (平均は 2.0 個, 最小は 1 個, 最大は 5 個 $)$ 。 後者については，208の記述が得られた（平均 2.1 個, 最小 0 個, 最大 6 個)。内容の分類については, 複数回にわたり，それぞれ別の複数の学生と協議 しながら検討した。

その結果，体型ポジティブ結果予期および体型 ネガティブ結果予期の両者ともに, 11 のカテゴ リーに分類可能であった。また, そのカテゴリー は，体型ポジティブ結果予期と体型ネガティブ結 果予期で対応していた。11のカテゴリーは，「自 己の肯定」,「積極的行動」,「同性からの評価」, 「異性からの評価」,「服の選択肢」,「㧍しゃれ」, $\lceil$ 身体の露出」,「二次的身体変化」,「魅力」,「将 来の成功」, そして,「健康」である。「自己の肯定」 は自信や自己に対する肯定感などについての内容 であり，「積極的行動」は，人前への出やすさな どについての内容であった。この「自己の肯定」 と「積極的行動」は, 自己の強化や自信の向上に 関連する内容であり，自分の目をとおした働きの あらわれといえる。つまり，従来の装いの対自的 機能に対応する内容と考えられた。また，「同性

7）教示はそれぞれ以下のと扬りである。「瘦せると, もしくは，瘦せていると，どのようなメリットがあ ると思いますか。下の枠の中に, 自由に書いてくだ さい。数はいくつでもかまいません。なお, 経験で も想像でもかまいません。」抢よび「太ると，もし くは太っているとどのようなデメリットがあると思 いますか。下の枠の中に，自由に書いてください。 数はいくつでもかまいません。なお，経験でも想像 でもかまいません。」である。

8）何名かについては, 講義終了後に実施した。
からの評価」は同性からの注目や反応に関する内 容であり，「異性からの評価」は異性からの注目 や反応に関する内容であった。この「同性からの 評価」および「異性からの評価」は, 他者からの 承認や相互作用の促進などに関連する内容であ り，他者の目をと扎した働きのあらわれといえ る。つまり，装いに扮ける対他的機能に対応する 内容と考えられた。以上, 装いと同様に, 瘦身に も対自的機能と対他的機能という心理的機能の存 在が想定されうることが確認された。このことは 同時に，瘦身が装いの1つであることを示したと いえる。

また，「服の選択肢」，「おしゃれ」，および「身 体の露出」というカテゴリーも抽出された。これ らは，他の装いの促進という特徵を有しており， 装い促進機能とでもいえる機能に対応したものと いえる。これまで，体型についての意識と衣服の 着用との関連が示されている (中野, 1986 ; 植竹, 1988）。そして, 瘦せを求める理由に衣服という 要因が関連していることも示されている（廣金 他，2001；北川・城戸 - 武安 ·加藤，1997）。さ らに, 装いと承認欲求との関連の検討から, 人々 がその時の自分の興味・関心，または状態に応じ て, 戦略的に装いを選択している可能性も示唆さ れている（鈴木，2008）。今回の結果は，体型が 他の装いの前提条件になっていることを示してお り，装いがそれぞれ密接に関連し，ある装いが他 の装いの前提条件になっていること，少なくとも そのように認知されていることを示唆したといえ る。本研究により, 大枠である装いについての有 用な知見も得ることができたといえる。

ほかのカテゴリーの内容は, 以下のとおりであ る。「二次的身体的変化」は, いわゆる部分瘦せ に関する内容であり，二の腕の細さやウエストの くびれに関する内容であった。羽鳥（1999）など においても，瘦身のメリットの身体面に「小顔」 や「細い手足」といった部分瘦せがあることが示 されている。部分瘦せが現実的に可能かどうかは 
別とし，人々が単純に全体的に瘦せることを意識 しているのではなく，メリハリのついた身体，つ まりプロポーションの良い身体を目標として瘦せ を求めていることがうかがえる。また，「魅力」 は，見た目についての内容であり，いわゆる，瘦 せイコール美 (“Thin is beautiful”) という信念を 反映している内容と考えられた。美の基準は明確 ではなく主観的なものであるが，少なくとも，主 観的には瘦身と美が強固に結びついていることが 確認されたといえる。「将来の成功」も抽出され た。これは, 結婚や人生に関する内容であった。 体型と人生が結びついて認識されているのは興味 深いことといえよう。「健康」は, 体型と関連す る健康についての内容であり，体調や動きやすさ に関する内容であった。これは，装いの身体保護 機能に対応していると考えられた。生活習慣病な どがメディアを賑わせていることもあり，体型が 健康と結びついて認識されている可能性がある。

ところで，装うことによる感情の变化や生理的 な変化は抽出されなかった。その理由として, 体 型は化粧やアクセサリーのように短期間で変化さ れることが不可能であるために，その場での鋭敏 な反応としての感情の変化が意識されにくいとい うことが挙げられる。また, 生理的変化が得られ なかった理由として, 上記の理由と併せ, 生理レ ベルでの変化はそもそも体型に限らず自覚されに くいものであり, 内省報告で得るには難しいとい うことが挙げられる。

\section{研究 2}

\section{目 的}

体型結果予期と瘦身願望との関連について検討 する。特に，心理的機能に対応する体型結果予期 に着目し，その関連の強さを，ほかの予期におけ るそれと比較し, 特徵を明らかにする。そのため に，まず，体型結果予期を測定するための項目を 準備し, その後, 体型結果予期と瘦身願望との関 連性について検討する。

\section{方 法}

対象 関東圈の共学の大学 1 校と女子大学 3 校 の女子学生 184 名, および, 看護学校 1 校の女子 学生 69 名の計 253 名を対象とした。無効回答 9 名, 年齢が 30 歳以上の 3 名 ${ }^{9)}$, 年齢未記入の 8 名, さらに, 体重が未記入，もしくは，現在よりも大

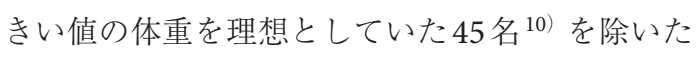
188 名（平均年齢 20.27 歳, 標準偏差 1.55）のデー 夕を以降の分析に使用した。なお,一部は他の調 査と併せて実施した。BMIの平均値は21.03（標 準偏差2.64）であった ${ }^{11) 。 ~}$

時期 2005 年 6 月から 7 月に実施した。

調査票 (a) 体型ポジティブ結果予期掞よび体 型ネガティブ結果予期を測定するための項目：研 究1で得られた自由記述の内容に基づいて作成し た項目である。複数回にわたり, それぞれ別の複 数の学生と協議しながら項目を作成した。なお, 体型ポジティブ結果予期と体型ネガティブ結果予 期の両者において, 同じカテゴリーでは項目内容 ができるだけ対応するように考慮した。この段階 では, 各カテゴリーについて4つから6つの項目 で構成されるようにした。それぞれの項目につい て, 回答者本人が普段, メリットやデメリットと 思っている程度について，「1. まったくそう思っ ていない」から「6. とてもそう思っている」の

9）年齢によって体型は変化し, またボディイメージ も変化する。そしてそれにともない, 装いも変わ り, また, 健康面への意識も変わると考えられる。 そこで, あえてここでは対象を一定範囲の年代 $(30$ 歳未満) に限定し, その年代の特徵を検討するこ とにした。

10）今よりも太りたいと思っている人にとっては, 現 在の体型へのネガティブな予期は, 瘦せているこ とのネガティブな結果の予期を意味することにな る。そのため, 今よりも太りたいと思っている人 のデータを分析から除外した。

11） 20 歳前後の女性の BMIの平均值は, ここ 10 年ほど 20.5 前後を推移している。今回の值は若干高めで はあるが，全体的には分布が一般的なそれと大き く異なっておらず，特に問題はないといえる。 
Table 1 体型ポジティブ結果予期と体型ネガティブ結 果予期の各カテゴリーの合成得点の平均值お よび標準偏差

\begin{tabular}{|c|c|c|c|c|}
\hline & \multicolumn{4}{|c|}{$N=188$} \\
\hline & \multicolumn{2}{|c|}{$\begin{array}{c}\text { 体型ポジティブ } \\
\text { 結果予期 }\end{array}$} & \multicolumn{2}{|c|}{$\begin{array}{c}\text { 体型ネガティブ } \\
\text { 結果予期 }\end{array}$} \\
\hline & $M$ & $S D$ & $M$ & $S D$ \\
\hline 自己の肯定 & 18.18 & 4.46 & 11.40 & 5.36 \\
\hline 積極的行動 & 14.43 & 4.95 & 11.56 & 5.66 \\
\hline 同性からの評価 & 17.22 & 4.76 & 10.96 & 4.68 \\
\hline 異性からの評価 & 15.92 & 4.85 & 13.81 & 5.27 \\
\hline 服の選択肢 & 19.46 & 4.59 & 16.31 & 5.58 \\
\hline おしやれ & 18.80 & 3.66 & 12.07 & 4.48 \\
\hline 身体の露出 & 21.49 & 3.33 & 16.84 & 5.23 \\
\hline 二次的身体変化 & 21.27 & 3.57 & 18.88 & 4.71 \\
\hline 魅力 & 19.49 & 4.00 & 15.46 & 5.62 \\
\hline 将来の成功 & 10.14 & 4.81 & 7.48 & 4.32 \\
\hline 健康 & 16.11 & 4.47 & 11.45 & 5.35 \\
\hline
\end{tabular}

6件法にて回答を求めた。

（b）瘦身願望尺度（馬場・菅原，2000）：瘦身 願望の程度を測定するための尺度である。11 項 目からなり，「1。まったくあてはまらない」から 「5. 非常にあてはまる」の5件法で回答を求めた。

実施方法 講義中に実施した。倫理的な配慮を おこない，同意を得た者のみを調査対象とした。

\section{結果および考察}

項目精選および予備的分析 カテゴリーごとに 項目分析をおこない，問題があると考えられる項 目から除外した。最終的に, 各カテゴリーの項目 数はそれぞれ4つとした。項目内容を Appendix I に示す。

各カテゴリーの項目の合成得点の平均值抒よび 標準偏差を Table 1 に示す。体型ポジティブ結果 予期と体型ネガティブ結果予期のそれぞれのカテ ゴリーごとにクロンバックの $\alpha$ 係数を算出したと ころ，若干高め $(\alpha \mathrm{s}=.82 \sim .96)$ であったが，大 きな問題はないとみなした。なお，体型ポジティ ブ結果予期と体型ネガティブ結果予期のそれぞれ に扮ける各カテゴリー間では，強く相互に関連し あうものがある一方，そうでないものもあること が示された（それぞれ $r s=.10 〜 .68$ と $r s=.03$
.70。Appendix II を参照)。また, 体型ポジティ ブ結果予期と体型ネガティブ結果予期の対応する カテゴリー間の関連の強さにも幅が見られた（ $r$ $=.20$. 54 。Appendix II を参照)。ある程度の強 さの関連が認められたため, 并別性を確認するた めに，カテゴリーごとに両者の項目をプールした 因子分析を実施した。分析の結果，十分に両者が 弁別されることが確認され ${ }^{12)}$, 両者はある程度 関連してはいるものの完全な表裏一体ではないこ とが示された。

体型結果予期と瘦身願望の関連 体型ポジティ ブ結果予期および体型ネガティブ結果予期と瘦身 願望との関連について，相関分析により検討した (Table 2)。その結果, 体型結果予期の各カテゴ リーと瘦身願望との間には, 一部を除き弱い関連 から中程度の関連が認められた（ $r s=.16 \sim .53 ） 。$

まず，心理的機能の1つである対自的機能に対 応する心理的効用（「自己の肯定」や「積極的行 動」) と瘦身願望との正の関連性が確認された。 特に「自己の肯定」においては全体の中では比較 的強い関連が示された。このことから，自身の目 をとおした効果への予期が瘦身願望を規定する主 な要因の 1 つであることが確認されたといえる。 例えば羽鳥（1999）においても，内容が限られる とはいえメリット意識とデメリット意識が瘦身 願望と関連しているという，類似した結果が示さ れている。

そして，同じく心理的機能の 1 つである対他的 機能に対応する心理的効用（「同性からの評価」 や「異性からの評価」) と瘦身願望との正の関連 性も確認された。例えば，菅原・馬場（2001）な どでも，他者から注目されるという瘦身のメリッ 卜意識が瘦身願望と関連しているという類似した 結果が示されている。今回の結果により, 同性や

12）基本的に, 初期解は最尤法, 回転方法はプロマッ クス回転とした。すべての結果を掲載することは 煩雑になると考えられたため, 割愛させていただ $<$ 。 
Table 2 体型ポジティブ結果予期および体型ネガティ ブ結果予期の各カテゴリーの合成得点と瘦身 願望尺度得点間のピアソンの積率相関係数

\begin{tabular}{lll}
\hline & \multicolumn{2}{c}{ 瘦身願望 } \\
\cline { 2 - 3 } & $\begin{array}{c}\text { 体型ボジティブ } \\
\text { 結果予期 }\end{array}$ & $\begin{array}{c}\text { 体型ネガティブ } \\
\text { 結果予期 }\end{array}$ \\
\hline 自己の肯定 & $.48^{* * *}$ & $.53^{* * *}$ \\
積極的行動 & $.35^{* * *}$ & $.41^{* * *}$ \\
同性からの評価 & $.41^{* * *}$ & $.28^{* * *}$ \\
異性からの評価 & $.41^{* * *}$ & $.35^{* * *}$ \\
服の選択肢 & $.28^{* * *}$ & $.40^{* * *}$ \\
拈しゃ机 & $.40^{* * *}$ & $.43^{* * *}$ \\
身体の露出 & $.41^{* * *}$ & $.47^{* * *}$ \\
二次的身体変化 & $.41^{* * *}$ & $.49^{* * *}$ \\
魅力 & $.49^{* * *}$ & $.44^{* * *}$ \\
将来の成功 & $.21^{* * *}$ & $.16^{*}$ \\
健康 & $.19^{* * *}$ & $.28^{* * * *}$ \\
\hline
\end{tabular}

$N=188,{ }^{*} p<.05,{ }^{* *} p<.01,{ }^{* * *} p<.001$

異性といった他者の目をとおした効果への予期も 瘦身願望を規定する重要な要因の1つであること が再確認されたといえる。

これらのように，心理面での効用についての認 知が瘦身願望と強く関連しており，心理的機能の 重要さが示された。心理面での効用を強く意識し ているために, 瘦せ過ぎの問題を身体面から論じ るような介入が受け入れられにくい可能性もあ る。この点は, 応用場面での介入をする際に考慮 する必要があり, 今後さらに検討する必要があろ う。

また，装い促進機能に対応している体型結果予 期と瘦身願望との正の関連性も確認された。この ことから, 他の装いのために瘦身を求めているこ とが示され，身体が他の装いの前提条件となって いることが再確認されたといえる。これまでの研 究にて示唆されてきた体型に関する諸意識と衣服 との関連（廣金他，2001; 北川他, 1997 ; 中野, 1986 ；植竹，1988）を支持する結果ともいえる。 さらに, 関連の強さが心理的機能についてのそれ と同程度であることから, 研究 1 においても示唆 されていた装い促進機能の重要性が再確認された
といえる。人々は，体型だけを意識しているので はなく，積極的に全体的な装いを意識して構築し ようとしていることがうかがえる。

ところで, 瘦身願望との関連性が確認されない 体型結果予期も見受けられた ${ }^{13)}$ 。体型ポジティ ブ結果予期の「健康」と瘦身願望との関連は認め られなかったが，これは，今回対象とした年代が 健康面よりも外見を重視しており（野口・高橋・ 岡庭, 1999 ; 渡辺 $\cdot$ 山沢 $\cdot$ 佐竹 - 松井 $\cdot$ 真鍋 $\cdot$ 上 野・大森, 1997), また, その多くが, 健康管理 が必要なほど太っているわけではないために, こ のような結果になった可能性がある。健康管理が 意識される他の年代や性別を対象とした場合は, 異なった結果になる可能性もある。また，体型不 ガティブ結果予期の「将来の成功」と瘦身願望の 関連も認められなかった。これは, この年代が未 来や過去に比べ現在のことを重視しているために (白井, 1989), 関連が見られなかった可能性もあ る。もしくは, そもそも将来について具体的なイ メージが抱けないために, このような結果となっ た可能性も考えられる。

ただし，解釈を慎重におこなう必要もある。今 回, カテゴリーの得点のいくつかに抽, 分布 の偏りが示されている。その分布の偏りが関連性 に影響を与えている可能性もある。例えば上記の 「将来の成功」と瘦身願望との関連の低さも, カ テゴリーの得点に床効果が生じているために生じ た可能性がある。今後検討を進める際には, 得点 の分布にも注意して項目を精選しなおすことも必 要かもしれない。

\section{ま と め}

本研究では, 瘦身の心理的効用についての検討 をとおし，装いとしての瘦身の心理的機能につい て明確にすることを目的した。そのために，以下

13）有意性の検定の結果は有意であったが, 相関係数 そのものは低い值であった。 
の2つの研究を実施した。第一に, 体型結果予期 の内容の分類と検討をおこなった。その結果，さ まざまな機能に対応する効用が抽出され，そこに は, 心理的効用の存在が認められた。これにより， 装いの心理的機能と同様の心理的機能が瘦身にも 存在することが確認された。第二に，体型結果予 期と瘦身願望との関連について検討した。その結 果, 両者の正の関連性が示された。そして, 心理 的機能に対応する体型結果予期と瘦身願望の関連 性が，他の機能におけるそれと同様に認められる ことが確認された。

今後は, 他の年代の女性, そして男性も対象に, 同様の検討をおこなうことが有益と考えられる。 その際には，今回若年女性において瘦身願望との 関連が見られなかった内容や，各対象の独自の内 容も考慮し検討することが有用であろう。このこ とにより, 瘦身の機能がより明確になると考えら れる。

また，体型ポジティブ結果予期と体型ネガティ ブ結果予期の影響についてより詳細に検討するこ とも有用と考えられる。例えば，体型についての 意識や行動に対して, 体型結果予期の一方のみが 影響している場合，もしくは，交互作用的な影響 を有している場合も考えられる。その点を明らか にすることは，応用場面等にても有用と考えられ る。

\section{引用文献}

赤松利恵 · 大竹恵子 - 島井哲志 (2003)。減量に扔ける 意思決定バランス尺度と行動変容の段階——隇量の 意思決定バランス尺度 (DBI) 日本語版作成と信頼性, 妥当性の検討—— 健康心理学研究, 16, 1-9.

飽戸 弘 (1982). 化粧意識と化粧行動の研究 飽戸 弘・鈴木裕久・田崎篤郎・嶋田智光（著）経済心理 学——ーケティングと広告のための心理学— 朝倉書店 pp. 85-95.

Allen, K. M., Thombs, D. L., Mahoney, C. A., \& Daniel, E. L. (1993). Relationships between expectancies and adolescent dieting behaviors. Journal of School Health, 63, 176-181.
馬場安希・菅原健介（2000）。女子成年に打ける瘦身願 望についての研究 教育心理学研究, 48, 267-274.

大坊郁夫 (1997). 魅力の心理学 ポーラ文化研究所

Demello, M. (2007). Encyclopedia of body adornment. Westport, Conn: Greenwood Press.

藤原康晴（1987）。女子大生の好きな被服のイメージと 自己概念との関連性 日本家政学雑誌，38，593-598. 羽鳥素子 (1999)。現代女性の瘦身願望——瘦身に対す るメリット意識の構造——平成 11 年度聖心女子大 学卒業論文 (未公刊)

平野和子 (2002). 女子学生のボディイメージとダイエッ 卜行動について 神戸文化短期大学研究紀要, 26, $1-12$.

廣金和枝 · 木村慶子 · 南里清一郎 · 米山浩志 - 齊藤郁 夫（2001）. 女子中学生のダイエット行動に関する研 究——学校保健に扮けるダイエット行動尺度の活 用——学校保健研究, 40, 175-182.

石田かおり（2000）。化粧せずには生きられない人間の 歴史 講談社

石井政之（2003）。肉体不平等一人はなぜ美しくなり たいのかー一平凡社

Kaiser, S. B. (1985). The social psychology of clothing and personal adornment. New York: Macmillan Publishing. 北川俶子 ·城戸摂子 ·武安典代 · 加藤達雄（1997）。摂 食障害に関する研究（女子大学生に打ける食行動, 体重変動, 心理状態に関する系統的調査研究）食に 関する助成研究調查報告書, 10, 115-125.

Kligman, A. M. (1985). Medical aspects of skin and its appearance. In J. A. Graham \& A. M. Kligman (Eds.), The psychology of cosmetic treatments. New York: Prager. pp. 3-25.

（クリグマン， A．Ｍ．早川律子（訳・監修）（1988）。 化粧の心理学 週刊粧業)

神山進 (2003). 被服の社会心理学的研究——特集号 の刊行によせて——瀻維製品消費科学, 44, 635636.

倉元綾子（2000）。若者のダイエット経験と食生活の実 態 鹿児島県立短期大学紀要, 51, 51-69.

松井 豊·山本真理子 ·岩男寿美子 (1983)。化粧の心 理的効用 マーケティング・リサーチ， 21，30-41.

松本聰子・熊野宏昭 - 坂野雄二 ・ 野添新一 (2001). 体 型や食事に関する信念尺度作成の試み——摂食障害 に打ける偏った思考パターンを探る—— 心身医学， 41, 335-342.

McArthur, L. H., \& Howard, A. B. (2001). Dietetics majors' weight-reduction beliefs, behaviors, and 
information sources. Journal of American College Health, 49, 175-181.

McFarlane, T., Polivy, J., \& McCabe, R. E. (1999). Help, not harm: Psychological foundation for a nondieting approach toward health. Journal of Social Issues, 55, 261-276.

中野 広（1986）。女性の服装美と体型 繊維製品消費 科学, 27, 330-335.

西岡光世 · 矢崎美智子 · 岩城宏明 - 桜井幸子 · 原田節 子・大澤清二 (1993). 若年女子のダイエット行動の 動機に関する研究 学校保健研究, 35, 543-556.

野口美恵子 ·高橋尚志 · 岡庭千代乃 (1999). ダイエッ 卜に関する意識調査一女子短大生と高校生の比 較——明和学園短期大学紀要, 14, 19-34.

O’Connell, D., \& Velicer, W. F. (1988). A decisional balance measure and the stages of change model for weight loss. International Journal of the Addictions, 23, 729-750.

尾田貴子 · 橋本幸子 · 柏尾眞津子 . 土肥伊都子 (2003). おしゃれの二面性に関する研究——被服 ·化粧行動, 心理的健康との関連——繊維製品消費科学, 44 , 700-709.

Paxton, S. J., Wertheim, E. H., Gibbons, K., Szmukler, G. I., Hillier, L., \& Petrovich, J. L. (1991). Body image satisfaction, dieting beliefs, and weight loss behaviors in adolescent girls and boys. Journal of Yourth and Adolescence, 20, 361-379.

Roach-Higgins, M. E., \& Eicher, J. B. (1992). Dress and identity. Clothing and Textiles Research Journal, 10, $1-8$.

Rojo, L., Livianos, L., Conesa, L., Garcia, A., Dominguez, A., Rodrigo, G., Sanjuan, L., \& Vila, M. (2003). Epidemiology and risk factors of eating disorders: A two-stage epidemiologic study in a Spanish population aged 12-18 years. International Journal of Eating Disorders, 34, 281-291.

Sabiston, C. M., \& Crocker, P. R. E. (2005). Examining current-ideal discrepancy scores and exercise motivations as predictors of social physique anxiety in exercising females. Journal of Sport Behavior, 28, 68-85.
Santoncini, C. U., Garcia, F. J., \& Peresmitre, G. G. (2006). Psychometric properties of the attitudes towards body figure questionnaire in Mexican female students and patients with eating disorders. European Eating Disorders Review, 14, 430-435.

白井利明 (1989). 現代青年の時間的展望の構造 (1) 一大学生と専門学校生を対象に一 大阪教育大 学紀要第 IV 部門, 38, 21-28.

Silberstein, L., Striegel-Moore, R., Timko, C., \& Rodin, J. (1988). Behavioral and psychological implications of body dissatisfaction: Do men and women differ? Sex Roles, 79, 219-233.

Spangler, D. L., \& Stice, E. (2001). Validation of the beliefs about appearance scale. Cognitive Therapy and Research, 25, 813-827.

菅原健介・馬場安希 (2001)。現代青年の瘦身願望につ いての研究——男性と女性の瘦身願望の違い— 日本心理学会第 65 回大会発表論文集, 69.

杉森智徳 (1999). ダイエットと食行動異常に関する研 究—ダイエットから摂食障害へ至るプロセスの検 討——平成 11 年度東洋大学大学院文学研究科修士 論文 (未公刊)

鈴木公啓 (2005). 装いとしてのダイエットーーイメー ジ, そして興味と経験の側面から—— 繊維製品消 費科学, 46, 725-731.

鈴木公啓 (2008).「装い」としてのダイエットと瘦身 願望—印象管理の視点から— 2007年度東洋大 学大学院社会学研究科博士論文 (未公刊)

植竹桃子（1988）。衣服設計の立場からみた肥り瘦せの 意識 日本家政学会誌, 39, 711-723.

浦上涼子. 小島弥生 · 沢宮容子 ·坂野雄二 (2009). 男 子青年における瘦身願望についての研究 教育心理 学研究, 57, 263-273.

渡辺周一 - 山沢和子 - 佐竹泰子 - 松井信子 - 真鍋良 子 ·上野良光 · 大森正英 (1997). 青年期女子の体重 観と日常生活 東海女子短期大学紀要, 23, 91-105. 余語真夫 · 浜 治世・津田兼六 ·鈴木ゆかり · 互 恵 子 (1990). 女性の精神的健康に与える化粧の効用 健康心理学研究, 3, 28-32.

- 2010.6.22受稿, 2012.5.28受理一 


\title{
Clarifying the Psychological Functions and Cognitions of Slimness Using the Conceptualization of Adornment
}

\author{
Tomohiro SUZUKI \\ Tokyo Future University
}

The Japanese Journal of Personality 2012, Vol. 21 No. 2, 164-175

Slimness and dieting are considered as aspects of adornment. We hypothesized that slimness, similar to adornment, has two psychological functions: for oneself and for others. In this study, positive and negative aspects of body outcome expectancies were examined to clarify cognitions about the functions of slimness. In Study 1, descriptions were obtained from participants and classified into 11 categories. Slimness had the same psychological functions for self and others as had been found for adornment. In Study 2, the relationship between body outcome expectancies and the drive for thinness was examined. To measure the degree of body outcome expectancies, items were developed based on the descriptions obtained in Study 1. Pearson's $r$ between these scores and the drive for thinness score were calculated, which showed positive relationships.

Key words: dieting, adornment, psychological function, outcome expectancy, drive for thinness

Appendix II 体型ポジティブ結果予期および体型ネガティブ結果予期のそれぞれにおける各カテゴリーの得点間のピ アソンの積率相関係数および両者の対応するカテゴリー間のピアソンの積率相関係数

\begin{tabular}{|c|c|c|c|c|c|c|c|c|c|c|c|}
\hline & 1 & 2 & 3 & 4 & 5 & 6 & 7 & 8 & 9 & 10 & 11 \\
\hline 1. 自己の肯定 & $.47^{* * *}$ & $.68^{* * *}$ & $.59^{* * *}$ & $.52 * * *$ & $.17^{*}$ & $.52 * * *$ & $.55^{* * *}$ & $.51^{* * *}$ & $.65^{* * *}$ & $.42 * * *$ & $.32 * * *$ \\
\hline 2. 積極的行動 & $.70^{* * *}$ & $.54 * * *$ & $.57^{* * *}$ & $.62^{* * *}$ & $.23^{* *}$ & $.58^{* * *}$ & $.45^{* * *}$ & $.37 * * *$ & $.49^{* * *}$ & $.63^{* * *}$ & $.27^{* * *}$ \\
\hline 3. 同性からの評価 & $.44^{* * *}$ & $.53^{* * *}$ & $.41^{* * *}$ & $.70^{* *}$ & $.19^{* * *}$ & $.49^{* * *}$ & $.45^{* * *}$ & $.43^{* * *}$ & $.53^{* * *}$ & $.35^{* * *}$ & .13 n.s. \\
\hline 4. 異性からの評価 & $.46^{* * *}$ & $.69^{* * *}$ & $.61^{* * *}$ & $.43^{* * *}$ & $.33^{* * *}$ & $.55^{* * *}$ & $.42 * * *$ & $.40 * * *$ & $.64^{* * *}$ & $.47^{* * *}$ & $.20 * *$ \\
\hline 5. 服の選択肢 & $.35^{* * *}$ & $.41^{* * *}$ & $.28^{* * *}$ & $.40^{* * *}$ & $.47^{* * *}$ & $.46^{* * *}$ & $.34^{* * *}$ & $.34^{* * *}$ & $.23^{* *}$ & $.16^{*}$ & $.28 * * *$ \\
\hline 6. おしゃれ & $.57 * * *$ & $.64^{* * *}$ & $.50^{* * *}$ & $.63^{* * *}$ & $.61^{* * *}$ & $.34^{* * *}$ & $.48^{* * *}$ & $.38^{* * *}$ & $.57^{* * *}$ & $.40^{* * *}$ & $.24^{* *}$ \\
\hline 7. 身体の露出 & $.39 * * *$ & $.50 * * *$ & $.38^{* * *}$ & $.50^{* * *}$ & $.56^{* * *}$ & $.60^{* * *}$ & $.20^{* *}$ & $.55^{* * *}$ & $.62^{* * *}$ & $.20^{* *}$ & .12 n.s. \\
\hline 8. 二次的身体変化 & $.38^{* * *}$ & $.37^{* * *}$ & $.20^{* *}$ & $.37 * * *$ & $.54^{* * *}$ & $.42^{* * *}$ & $.71^{* * *}$ & $.29 * * *$ & $.43^{* * *}$ & .10 n.s. & $.19^{*}$ \\
\hline 9. 魅力 & $.48^{* * *}$ & $.61^{* * *}$ & $.52^{* * *}$ & $.68^{* * *}$ & $.46^{* * *}$ & $.69^{* * *}$ & $.70^{* * *}$ & $.58^{* * *}$ & $.37^{* * *}$ & $.30^{* * *}$ & $.18^{*}$ \\
\hline 10. 将来の成功 & $.54^{* * *}$ & $.58^{* * *}$ & $.44^{* * *}$ & $.43^{* * *}$ & $.22^{* *}$ & $.44^{* * *}$ & $.20^{* *}$ & .03 n.s. & $.33^{* * *}$ & $.53^{* * *}$ & $.29 * * *$ \\
\hline 11. 健康 & $.46^{* * *}$ & $.35^{* * *}$ & $.21^{* *}$ & $.20^{* *}$ & $.47^{* * *}$ & $.46^{* * *}$ & $.28^{* * *}$ & $.37 * * *$ & $.23^{* *}$ & $.36 * * *$ & $.35^{* * *}$ \\
\hline
\end{tabular}

$N=188,{ }^{*} p<.05, * * p<.01, * * * p<.001$

注. 対角右上が体型ポジティブ結果予期内のピアソンの積率相関係数。対角左下が体型ネガティブ結果予期内のピアソンの積率相 関係数。対角が両者の対応するカテゴリーの得点間のピアソンの積率相関係数。 
Appendix I 体型ポジティブ結果予期および体型ネガティブ結果予期のカテゴリー名および項目内容

\begin{tabular}{|c|c|c|}
\hline & 体型ポジティブ結果予期 & 体型ネガティブ結果予期 \\
\hline \multirow[t]{4}{*}{ 自己の肯定 } & 自分に満足できるようになる & 自分を好きになれない \\
\hline & 自分を好きになれる & やる気がでない \\
\hline & 自分に肯定的になれる & 悩み事が減らない \\
\hline & 明るい気分でいられる & 明るい気分でいられない \\
\hline \multirow[t]{4}{*}{ 積極的行動 } & 積極的に遊びに出かけることができる & コンパやパーティーに参加しにくい \\
\hline & 異性に積極的に話しかけることができる & 異性に積極的に話しかけにくい \\
\hline & 新しい友達をたくさんつくることができる & 人前に出るときに引け目を感じる \\
\hline & ひけめを感じずに人前に出ることができる & 恋愛に前向きになれない \\
\hline \multirow[t]{4}{*}{ 同性からの評価 } & 同性からうらやましがられる & 同性受けが良くない \\
\hline & 同性からほめられる & 同性に注目されない \\
\hline & 同性受けが良くなる & 同性に良い印象をもってもらえない \\
\hline & 同性から注目される & 同性に高い評価をもらえない \\
\hline \multirow[t]{4}{*}{ 異性からの評価 } & 異性の注目をひくことができる & 異性受けがよくない \\
\hline & 異性から好かれる & 異性の注目をひけない \\
\hline & 異性からほめられる & 異性にモテない \\
\hline & 異性にデートに誘われる & 異性にほめてもらえない \\
\hline \multirow[t]{4}{*}{ 服の選択肢 } & 服のサイズで困らなくなる & 細身の服を着れない \\
\hline & 洋服のサイズを気にせず着れる & 服を着るときサイズが気になる \\
\hline & 好みの服をサイズを気にせず購入できる & 好みの服のサイズがなくて購入できない \\
\hline & 購入時に服の選択の幅が広がる & 購入時に服の選択の幅が限定される \\
\hline \multirow[t]{4}{*}{ おしゃれ } & 服が似合うようになる & 服をかっこよく着れない \\
\hline & おしやれを楽しめる & オシャレを楽しめない \\
\hline & アクセサリーが似合う & アクセサリーが似合わない \\
\hline & 化粧を楽しめるようになる & 化粧を楽しめない \\
\hline \multirow[t]{4}{*}{ 身体の露出 } & 水着を着れる & 水着になれない \\
\hline & 足が出せる & 足が出る服を着れない \\
\hline & 二の腕が出せる & 二の腕が出せない \\
\hline & 体のラインが出る服を着れる & 体のラインが出る服を着れない \\
\hline \multirow[t]{4}{*}{ 二次的身体変化 } & 脚が細くなる & 二の腕が細くない \\
\hline & 二の腕が細くなる & ウエストにくびれがない \\
\hline & ウエストのくびれができる & スタイルが良くない \\
\hline & スタイルが良くなる & 脚が細くない \\
\hline \multirow[t]{4}{*}{ 魅力 } & かわいく見える & かわいく見えない \\
\hline & 見た目が良い & 見た目が良くない \\
\hline & きれいに見える & きれいに見えない \\
\hline & 魅力的に見える & 魅力的に見えない \\
\hline \multirow[t]{4}{*}{ 将来の成功 } & 幸せな結婚ができる & 幸せな結婚ができない \\
\hline & 幸せな家庭を築くことができる & 幸せな家庭を築くことができない \\
\hline & 幸せな人生をおくることができる & 幸せな人生をおくることができない \\
\hline & 良い仕事につくことができる & 良い仕事につけない \\
\hline \multirow[t]{4}{*}{ 健康 } & 健康的になる & 体調が良くない \\
\hline & 体調が良くなる & 健康的でない \\
\hline & 体への負担が少なくなる & 動きにくい \\
\hline & 体が動きやすくなる & 疲れやすい \\
\hline
\end{tabular}

